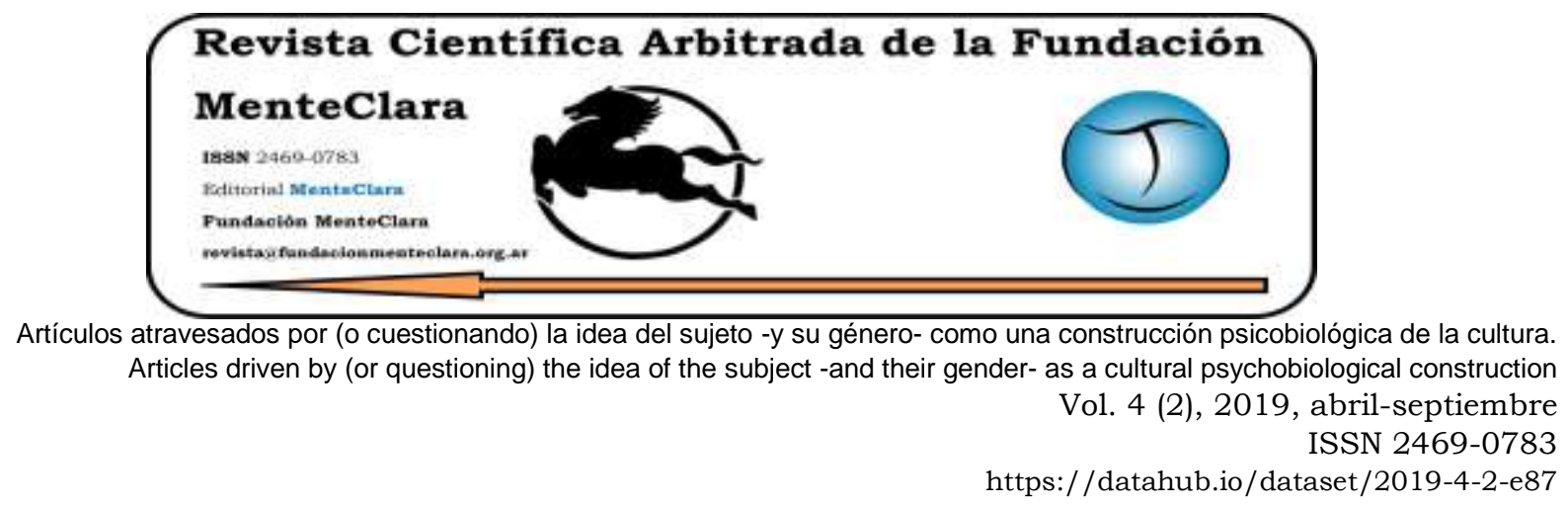

\title{
ONTOLOGY OF BLISS: A PHENOMENOLOGY
}

\author{
ONTOLOGÍA DE LA DICHA: UNA FENOMENOLOGÍA
}

Rudolph Bauer rbauer@rsbauer.net

Center for Consciousness Studies and Washington Center for Phenomenological and Existential Psychotherapy Studies. United States of America

Cómo citar este artículo / Citation: Bauer R. (2019). "Ontology of Bliss: A Phenomenology". Revista Científica Arbitrada de la Fundación MenteClara, 4(2) abrilseptiembre 2019, 55-70.

DOI: https://doi.org/10.32351/rca.v4.2.87

Copyright: (C) 2019 RCAFMC. Este artículo de acceso abierto es distribuido bajo los términos de la licencia Creative Commons Attribution 4.0 International License (CC BY 4.0). Recibido: 02/07/2019. Aceptado: 16/07/2019 Publicación online: 30/10/2019

Conflicto de intereses: None to declare.

\begin{abstract}
The article is about the ontology of bliss. Bliss is an ontological experience and not simply a feature of one's personal psychology of mind. Bliss intrinsically reflects our experience of Being. The paper intertwines and integrates Heideggerian ontology within the experience of Bliss as documented in the Dudjom Tersar from the 19th century esoteric teachings of the Tibetan tantric master Dudjom Lingpa. The paper emphasizes the tantric declaration that "Bliss Overcomes Suffering" and this experience of Bliss arises naturally out of the existential praxis of living within the ongoing continuity of the experience of Being.
\end{abstract}

\section{Resumen}

Este artículo trata sobre la ontología de la dicha. La dicha es una experiencia ontológica y no simplemente una característica de la psicología personal de la mente. La dicha refleja intrínsecamente nuestra experiencia del Ser. El documento entrelaza e integra la ontología heideggeriana dentro de la experiencia de dicha como se 
documenta en el Dudjom Tersar de las enseñanzas esotéricas del siglo XIX del maestro tántrico Dudjom Lingpa. El artículo enfatiza la declaración tántrica de que "la dicha vence el sufrimiento" y esta experiencia de dicha surge naturalmente de la praxis existencial de vivir dentro de la continuidad de la experiencia del ser.

Keywords: Tantra; existence; happiness; bliss Heidegger; Dudjom; Rigpa

Palabras Claves: Tantra; existencia; felicidad; dicha; Heidegger; Dudjom; Rigpa 


\section{Introduction}

This paper is on the ontology of Bliss. Amazingly, Bliss is an ontological experience and not simply a function of our personal psychology of mind. Bliss is not simply having a good day, or dare I say, an exceptional day. Bliss is not simply a good feeling on a good day. Bliss reflects our experience of Being, just as we are. Bliss reflects our "sense" of Being in every situation, in every context, in every mood, and in every event. Bliss reflects our experience of our awareness becoming aware of Being in all the various circumstances of our unfolding life. Bliss is our sense of the ontological manifestation of Being. Bliss is the experience of our sense of the Ontological dimension of Being. Bliss is within Being itself. Bliss is not simply an emotional conjuring. Bliss is our direct sense of the nature of Being as Bliss. Our direct "sense" of our nature of our own Being is Bliss!

To use Heideggerian language Bliss is not simply an ontic experience. Our sense of Bliss is ontological. Bliss is a characteristic of the Ontological Dimension of Being.

\section{Beyond Good and Evil}

The Bliss of Being is in the realm of good and evil, and yet the Bliss of Being is beyond the realm of good and evil. The Bliss of Being is beyond right and wrong, beyond good and evil, beyond better and best, and the Bliss of Being is even beyond truth and falsity. When the Veda's declare Sat Chit and Ananda ${ }^{1}$, they are declaring the Ontology of Bliss. Being is Awareness and Being is Bliss. Existence is Consciousness, and Existence is Bliss. This is an ontological description of the nature of Being.

\footnotetext{
${ }^{1}$ In Sanskrit Truth, Consciousness and Bliss.
} 
The Bliss we experience is actually the Bliss of Being. Bliss is within the nature of Being. Bliss is not simply our experience of Being, but within our experience of Bliss we directly 'sense' what is Being, and what is within Being. We sense the Bliss of Being within Being. The invisible becomes visible! We can experience Being within our own being and within the Being of beings.

This understanding of our direct non-conceptual pre-reflective knowingness as "Sense" is a wonderful contribution of Maurice Merleau Ponty's unfolding Ontology of Being. Merleau Ponty brings forth our sense of knowing, our sense of knowing the meaning of Being within phenomena, and the meaning within the Being of the phenomena. Merleau Ponty's phenomenology of "sense" opens us to the experience of the ontological dimension of the Being of meaning as well as of the meaning of Being. There is a meaning within Being itself. This meaning is not something we impose on Being. There is meaning within Being itself. Bliss is such a meaning within Being.

\section{Our "Sense" of what is within Being}

It really is true, there are two ways of knowing. Merleau Ponty knew this drama of our two ways of knowing. His understood the unfolding of phenomenology as a discovery of two ways of knowing. He understood that the union of the two ways of knowing brings forth our "Sense" of the Being of phenomena and our "Sense" of the phenomena of Being. His non-conceptual pre-reflective understanding of direct knowingness as a "sense" reflects the union of our two ways of knowing within the one knower. 


\section{Husserl's Phenomenology of Intentionality of Mind}

His unfolding of his understanding of the power of phenomenology began with his articulation of Husserl's phenomenology of mind, and the corresponding intentional constitution of the knowing of our experience of phenomena. His later studies at the University of Leuven, opened up for Merleau Ponty the direct non-conceptual pre-reflective knowing of phenomena and within phenomena the direct knowing of field of Being.

\section{Pre-Reflective Non-Conceptual Knowing of Awareness}

There is a direct sense of knowing which is the knowing of awareness. Awareness knows Being. Mind knows phenomena. The direct knowing of the appearance of phenomena opened for Merleau Ponty, the direct knowing of the "sense" of the field of Being within phenomena. Through the phenomenology of appearance, the sense of the field of Being manifested. This union of knowing, was the union of the knowing of mind within the knowing of awareness. "Sense" reflects this union of the two modes of knowing within the one knower!

The first phenomenology was the knowing of mind, and the later phenomenology was the unfolding of the direct knowing of awareness. The direct knowing of awareness is the direct knowing of Being. Our "sense" of knowing, is our direct sense of knowing through the phenomena of appearance into the phenomena of Being. The Invisible becomes Visible! We can know Being through the appearance of beings. Being self-manifests as beings. The Beingness of Being is the Beingness of a being. The Beingness of a being is the Beingness of Being. Being is self- manifesting as the invisible of the visible. Being can be experienced though the visibility of beings. The Beingness of a being, is the Beingness of Being itself. 


\section{The Distinction Within Ancient Dzogchen}

This same great distinction between knowing through mind and knowing through awareness is considered of the utmost importance in the ancient Dzogchen tradition of the Nyingma Tibetan Buddhism. This distinction was made in the $8^{\text {th }}$ century AD. The union of mind and awareness was experienced as the Dzogchen medium of natural selfliberation in our life "just as it is".

\section{The Same Distinction within Psychoanalysis}

This same distinction between mind and awareness was made in the world of psychoanalytic understanding by Donald Winnicott. Winnicott made this distinction between the experience of mind and the experience of transitional space of awareness. This distinction was made in the 1960's. Winnicott also understood that the nature of the self was the nature of Being. Through the experience of transitional awareness, the sense of self becomes manifest. Winnicott would often describe the 'sense of self', as the ongoing continuity of our sense of Being. This understanding becomes most important in the praxis of self-liberation that psychotherapy offers for so many.

\section{Our Two Ways of Knowing and Their Union}

There is knowing through our mind. Our mind knows through thoughts, through feelings, through sensations, through memory, and through imagination. Our mind knows forms, and knows things and beings. Our mind knows me and you, us and them, and this and that. Our mind knows the subtle actualities of phenomena and our mind knows vast cosmological actualities. Our mind is fantastic. Our mind is relational. Our mind knows duality. Our mind has vast emotional range, 
vast intelligence, vast imagination, and our mind can remember all kinds of experience. Our memory actually supports our sense of self as narrative. Our mind has the most exquisite capacity for pleasure and for pain. Our mind is dualistic. Our mind knows subject and otherness. Our mind knows difference. Our mind knows form. Our mind knows the form of beings. Our mind does not know Being itself. Our mind can think of Being and think about the Being of beings but our mind does not directly sense Being. Our awareness knows Being and experiences Being, and "senses" Being. Our awareness "senses" the Being of beings.

Our mind can be intimately influenced by the Bliss of Being because of our mind's intimate connection with the field of awareness. Often however, our mind may unhappily dissociate from our innate field of innermost awareness. Our mind is deeply conscious and deeply unconscious with its connection to the field of Being. In its profound levels the mind is the experience of the duality of the instinctiveness of Eros and Thanatos. Eros and Thanatos are the ontological manifestations that become personified as the somatic-psyche instinctiveness of Eros and Thanatos.

\section{Awareness of Awareness}

We know Being through our awareness. We know through our awareness of awareness. Awareness directly knows Being. Awareness knows directly the Being of phenomena as well as the phenomena of Being. Awareness knows Being, and our awareness is our Being's knowingness. Our Being knows Being within itself and our Being knows Being within phenomena. This knowingness is self-liberation.

We are one knower with these two ways of knowing. When our mind and awareness are integrated, we can directly and knowingly "sense» 
Being within the phenomena of appearance, and we can "sense" directly the phenomena of Being itself. We can directly "sense" Being within our self and we can directly "sense" the phenomena of Being within others and within the world itself. This sense of Being opens for us the bliss of Being within our self, and within others, and within the unfolding events of time. Being unfolds as time!

\section{Personification of Being}

Our self is our personification of Being, our personification of the Being that we are. Our self is not a thing, or a conceptualization or a cognitive schema as some would have you think. Our self is our personification of our Being. Our sense of self and our sense of Being converge. Our awareness is the knowing of our Being. Our mind in union within our awareness allows us to "sense" the Being of phenomena and the phenomena of Being simultaneously. Our union of mind and awareness brings forth our direct "sense" of phenomena and the "sense" of the Being of phenomena simultaneously.

Our awareness is our Being's knowingness of Being. Awareness is our being's knowingness. Awareness is the field of our Being knowing the field of Being of everything and anything. Our Being is a field of Being that is Being itself manifesting as 'you and as I'. The field of Being is a phenomenal field. The phenomenal field is the field of Being knowing the phenomena of Being and the Being of phenomena.

\section{Resonance of Mind and Resonance of Awareness}

Our mind knows phenomena. Our mind has a "sense" of phenomena. Our mind resonates with and within phenomena, and our awareness resonates with and within the field of Being. This union creates the power 
of our direct sense of knowing phenomena and Being simultaneously. This direct "sense" allows us to know the Being of phenomena and the phenomena of Being. This knowing "sense" is our resonance through and within the appearance of phenomena into the our direct "sense" of field of Being. This is the wonderful power of our "sense" of direct knowing. Our sense of direct knowing is the field of the one knower; knowing through mind and through awareness simultaneously. Our "sense" is our unified knowing as a field. Our field of knowing is our sense of knowing as the field of mind within the field of Being of our awareness. The sense of "sense" is the One Unified Field of knowing. This "sense" can know duality within non-duality and non-duality within duality. This "sense" can know the duality of beings within the non-duality of Being. This "sense" can know the non-duality of Being within the duality of Beings. This knowing is self-liberation.

\section{Qualities of The Field of Being}

The quality of the field of Being is spaciousness or openness. Another quality of the field of Being is vital energy. Another quality is luminous radiance. Directly related to the radiance of Being is the Pervasive Bliss of Being. Bliss is a quality of the Field of Being. Bliss is the radiance of the Field of Being.

\section{Bliss is not an Emotion of Mind}

Bliss is not an affect of our mind, and bliss is not an emotion of our mind. We can have many emotions about bliss and many emotions within our sense of Bliss within the field of Being. Bliss is the very nature of Being. Bliss is not an extra, Bliss is not an addition. Bliss is the nature of the field of Being. Bliss is the very nature of our field of awareness 
which is the field of Being in "us as us". The Nature of Being as our own Being is Bliss. The nature of Bliss is the nature of Radiance. The sense of the radiance of Being is our sense of the Bliss of Being within Being.

As we sense our embodied awareness and our embodiment of the field of Being within us, we experience this Bliss within us, which is the Bliss of the field of our own Being. Our sense of Bliss is reflecting what is actually in and within the nature of Being. This Bliss is not a construct of our mind. This is not a conceptual imposition on Being. Bliss is within and is intrinsic to the phenomena of Being. This is not transcendental idealism and not transcendental solipsism.

This Bliss of the field of Being does influence our sense of embodiment and does influence our sense of mind. Bliss does influence our thinking. Bliss does influence our affective states. Human beings are an intertwining of mind and awareness, the intertwining of mind and Being's knowingness. Our embodiment of Being is our sense of Being and our sense of Being is our sense of self. Our sense of Being and our sense of self converge into one convergent actuality of you and of me, of us.

\section{Convergence of Sense of Being and Sense of Self}

Our embodiment of our sense of Being is our sense of self. Our ongoing sense of self reflects our ongoing experience of our mine-ness of our own Being. Our ongoing sense of self reflects our innermost experience of our personification of Being. The realm of Being is both infinite in its horizon, vast and multidimensional. Being is also completely singular in its incarnation in becoming our being. The field of Being becomes a human being. A human being is a singular manifestation of the field of Being. A human personifies the field of Being and the Qualities of Being. A human 
being is who-ness, the who-ness of awareness. The who-ness of our awareness is our knowing as self.

\section{The Self Arising of Bliss}

As we experience our Self as the field of our Being, there is naturally the self- arising of Bliss. The self-manifestation of Bliss is the selfmanifestation of Being. Bliss is the experience of our nature of Being knowing Being. This Bliss infuses our mind and our embodiment. Bliss does not foreclose suffering. Bliss can overcome suffering. Bliss is not simply a function of goodness or evilness. Bliss is a function of experiencing and sensing the Being of our own Being. We all have the gift of sensing and experiencing the Being of phenomena and the phenomena of Being itself. Bliss is the Being of the world, and Bliss is the Bliss of Being itself. There is our sense of the Being of phenomena, and there is our sense of the phenomena of Being. If you and I are in mind alone, we will miss the Being of phenomena and the Phenomena of Being. We will miss the Bliss of Being.

\section{Institutionalization. Passivity and Deformation of Our Being}

To have this sense of Bliss, and to cultivate this sense of Bliss is wonderful and most important. This cultivation is possible for everyone in their life just as it is. You do not have to be institutionalized in the sense that Merleau Ponty speaks about institutionalization. Institutionalization means your sense of Being is organized by an organizational field or institutionalized field that dominates your sense of awareness. You are organized by a field of institutionalization and not directly by the field of Being. Merleau Ponty considers this passivity to 
reflect a field of institutionalization and not awareness of Being. This passivity may result in deformation of our sense of Being.

\section{Patriarchal Systems: Institutionalization of Bliss}

Patriarchal systems have the capacity of dominating our sense of Being as we think and believe that the patriarchal symbolic function possessed by patriarchal person or the patriarchal institution signifies that the Patriarchal Person or People are the "Ones Who Know". The Patriarchal person may seem to be the only One who has the power of Being and the power of the gift of Being. The power of the gift of Being is the power to give the Bliss of Being. The Patriarchal Institutional Organization and Patriarchal Person or Persons actually does have the power of the Gift of Being or the power of the Bliss of Being. And so does Everyone! Being itself is the power of Being and the power of Being is given to all of us. The Power of Being comes with the territory of Being a human being. All human beings have the power of Being, and the power of giving the Bliss of Being to each other. The great compassion is the power of giving the Bliss of Being to a person or persons.

The symbolic function is the very nature of us as multidimensional Beings. The symbolic function is the power of the archetypal dimension of Being which is within all beings as their Being. Patriarchal Institutions, political as well as religious, pretend that they alone have this power of the gift of Bliss. This pretense can undo the archetypal self-agency of everyone and anyone. This pretense saturates most religious cultures.

This pretense is even in the culture of phenomenology, someone appears to claim they are the only One who really knows. Of course, this pretense is pervasive in corporate culture, religious culture, and in cultures of healing. 


\section{Transcendental Limitation and Containment of Bliss of}

\section{Phenomena}

Transcendental states and transcendental traditions discover the phenomena of Being only in the transcendental realm. The phenomena of Being can be easily, most easily be discovered in the phenomena of our life of awareness and in the phenomena of the appearance of our world. The Bliss of Being can be experienced in and of itself as a natural phenomena of Being. Transcendental traditions discover the field of Being separate from phenomena and separate from mind itself. Transcendental traditions discover liberation through the radical dissociation from the field of Being as phenomena. Transcendental traditions dissociate from the phenomena of Being and they dissociate from the Being of phenomena.

In the non-dual traditions of immanence, the field of Being is experienced within the Being of phenomena, and within the pure phenomena of Being. In non-dual traditions of immanence, the most direct sense of Being and most direct experience of Being is within the phenomena of our awareness, which is the field of Being as our knowing. Through our becoming aware of our own awareness we experience the Bliss of the field of Being. By becoming aware of our own awareness, we experience our self as the field of Being and we experience our field of Being as our ongoing sense of self. We sense the field of Being in others, we sense the field of Being in everyone and everything. This is selfliberation.

\section{Sensing the Bliss of Being}

You can sense when a person embodies the field of Being. You can sense when a person experiences the Bliss of Being. You can sense when 
a person's actuality of reality is through their experiencing the Bliss of Being. Many people live in Bliss-less Being. Many people live in mind alone. Some people live in awareness without the integration of phenomena of appearance. They experience Bliss in a somewhat contained solipsistic way. They experience the Bliss of Pure Being but not within the Being of phenomena.

\section{For Some Bliss is Being A Clown}

The Bliss of Being is not simply being a happy clown, or the Bliss of Being a simpleton. Bliss is not a function of the mind alone. The sense of Bliss is a function of the union of our mind within the field of awareness of the Being of our own Being, as well as the Being of others, and Being in and of itself. The Bliss of Being is not a denial of suffering. The Bliss of Being is not the Bliss of Naivete. The Bliss of Being is not the bliss of $M a$ Rigpa $^{2}$ or stupidity. The Bliss of Being is the Bliss of Wisdom Gnosis. The Bliss of Being is the Bliss of jñana ${ }^{3}$. The Bliss of Being is the Bliss of Rigpa. This Bliss is available to everyone and anyone.

\section{Being of Phenomena and the Phenomena of Being}

The union of mind and awareness reflects the "sense" of the Being of phenomena and the phenomena of Being. It is the sublime union of mind knowing form and the knowing of awareness knowing Being which is the alchemical medium that brings forth the "sense" of the Being of phenomena and the phenomena of Being. In transcendental experience there is no mind. And there are no phenomena. There is only Pure Being.

\footnotetext{
2 Ignorance: Tibetan ma (no) and rigpa (knowledge).

${ }^{3}$ Knowledge in Sanskrit.
} 
The experience is the experience of I alone exist. The transcendental experience is incomplete in range.

\section{Conclusion}

Bliss Overcomes Suffering. Authentic human beings live in the Bliss of being. Bliss does not exclude horrible suffering, horrible illness, horrible lost, horrible grief, and horrible agony. Bliss is not conjuring up of idealistic solipsistic thought. Bliss is within the Being of phenomena and the phenomena of Being. The sense of Bliss is our sense of Bliss within Being and within the phenomena of Being. Bliss as Being itself is present in all events and all circumstances. Bliss is the experience of the manifestation of the fluidity of Being.

Being manifests the human experience with its infinite range and infinite variation of experience. Bliss integrates all affective states and all afflictive states. The integration of afflictive states in the field of awareness, allows the metabolization of these afflictive states of mind. The metabolization of states of mind is a function of the Radiance of awareness. The Radiance of awareness is ultimately the Bliss of Being.

Cultivating the sense of Bliss is the existential praxis of living the experience of Being and the given-ness of Being which is the given-ness of Bliss. 


\section{References}

Merleau-Ponty, M. (1968). The visible and the invisible, ed. Claude LeFort. Trans. by Alphonso Lingis. Evanston, IL: Northwestern University Press.

Morris, D. (2018). Merleau-Ponty's Developmental Ontology. Northwestern University Press.

Muktananda, S. (1982). Play of consciousness. SYDA Foundation.

Wallace B.A. (2015). Dudjom Lingpa's Visions of the Great Perfection, Vol 3. The Vajra Essence. Wisdom Publications. 